\title{
Dílo Jana Kollára ve světle klasicistních a romantických tendencí uherských literatur neo-latinské a školní latinské provenience
}

Róbert Kiss Szemán

\begin{abstract}
The work of Jan Kollár from the perspective of classicist and romantic tendencies in Hungarian neo-Latin and pedagogical Latin literature

The study deals with Ján Kollár's oeuvre in the light of the classicist and romantic tendencies of national cultures in Central Europe. The first part of the study addresses the place of Kollar's work within the canon of Classicism and/or Romanticism. The study states a significant difference between the Czech and Slovak reception of Kollár's work, which results from their inherent differencies. To evaluate the relevance of these questions today the study applies the methodology of postmodern and postcolonial cultural theory. The second part of the paper suggests a new perspective on Kollár's work - namely from the viewpoint of the Latin and Neo-Latin culture in Hungary in the $18^{\text {th }}$ end $19^{\text {th }}$ century.
\end{abstract}

\section{KEYWORDS}

Ján Kollár's oeuvre, Classicism and Romanticism in Central European literature, Latin and neo-Latin culture in Hungary.

\section{KLÍčOVÁ SLOVA}

Dílo Jána Kollára, klasicistní a romantická literatura střední Evropy, latinská a neolatinská vzdělanost v Uhrách. 


\section{Autorská pozice a vztah $\mathrm{k}$ předmětu}

Tato studie je zastávkou uprostřed dlouholeté badatelské práce, kterou jsem začal v prvním desetiletí nového tisíciletí a která byla zaměřena na textologický výzkum celku Kollárovy tvorby a na rekonstrukci jejího středoevropského kulturního kontextu. Jistá autobiografičnost studie ovšem nepramení z úmyslu subjektivizace, ale ze snahy určitého ujasnění autorské pozice, důsledkem kterého dokáže čtenář lokalizovat mluvčího, neboli si dokáže vytvořit komplexnější obraz nejen o vědeckých tezích obsažených ve studii, ale rovněž o pozici, z níž autor promlouvá. ${ }^{1}$ Aktuální mluvčí je přitom subjektem, jenž je na různých úrovních spojen s více středoevropskými národy, svou mad’arskou mateřštinou vrostl do slovenské kultury a navázal důvěrnou známost s českým a německým jazykem i kulturním prostředím. $Z$ toho vycházejí i jeho komparatistické ambice, s nimiž se přibližuje ke svému materiálu. ${ }^{2} \mathrm{O}$ Kollárovi tedy uvažuji v tomto kontextu a dosavadní výsledky získané pomocí tradičních filologických metod nechávám projít zkouškou ohně moderní literární vědy a na základě toho je zamýšlím uspořádat. Inspirován jsem přitom v neposlední řadě podvojnou Ricoeurovou hermeneutikou víry a podezření. ${ }^{3}$ To vše ve znamení určitého poznání, přítomného důrazně $\mathrm{v}$ postmoderně, podle nějž nit, zdánlivě vedoucí z labyrintu ne-vědění, vede do stále novějších a novějších labyrintů. Předkládaná studie tedy není pokusem o vyřešení, ale procesem zasvěcení, který zároveň konstruuje i de(kon)struuje. ${ }^{4}$

1) V tom smyslu, jak ji používá Ramón Grosfoguel ve studii A politikai gazdaságtan és a posztkoloniális tanulmányok gyarmatmentesítése. Transzmodernitás, határgondolkodás és globális gyarmatiság (Odkolonizování politické ekonomie a postkoloniálních studií), in Eszmélet, roč. 23, 2011, č. 92, s. 39-70. Viz především z kapitoly Ismeretelméleti kritika (Noetická kritika) na s. 42-44. „[...] naše promluva je vždy vázána na nějakou zvláštní situaci mocenských struktur,"s. 42. Mad’arský překlad Csala, Károly.

2) Ve výše uvedené studii mluví Grosfougel v souvislosti s lokalizací o třídní, centrální, periferní, politické, rasové, genderové, sexuální, spirituální, epistemické, jazykové hierarchii. Autor si je obvykle vědom neúplnosti jím stanovené lokalizace. Viz Grosfoguel, Ramón: „A politikai gazdaságtan és a posztkoloniális tanulmányok gyarmatmentesítése. Transzmodernitás, határgondolkodás és globális gyarmatiság“, in Eszmélet, roč. 23, 2011, č. 92, s. 39-70, 46.

3) Ricoeur, Paul: Freud und Philosophy. An Essay on Interpretation. Yale University Press, New Haven, 1970. Viz kapitoly Interpretation as recollection of Meaning (s. 28-32.) a Interpretation as exercise of suspicion (s. 32-36), ve kterých porovnává názory fenomenologů a velkých dekonstruktorů (Marx, Nietzsche, Freud) s důrazem na pozitivní přínos dekonstrukce: „destruction, Heidegger says in Sein und Zeit, is a moment of every new foundation [...]“, s. 33.

4) Heidegger v souvislosti s dekonstrukcí dějin ontologie píše, že tradice odřezává svojí zkamenělostí př́itomné bytí od jeho kořenů. Destrukce nemá negativní význam a musí být vymezena otázkami v rámci pozitivních možností ontologické tradice, tedy v rámci vlastních hranic. Viz Heidegger, Martin: Lét és idő (Bytí a čas). Budapest, Gondolat 1989, 6 §, s. 115. 


\section{Klasicismus - preromantismus - romantismus}

Zhruba půldruhého století se v českých a slovenských literárněvědných reflexích opakovaně setkáváme s otázkou, zda je možné Kollárovu tvorbu - která trvá od jeho studentských prvotin ${ }^{5}$ až po díla vydaná posmrtně ${ }^{6}$ zařadit spíše do kulturního kánonu klasicismu anebo romantismu. Historická relevance této otázky je nezpochybnitelná, avšak z dnešního recepčního pohledu se tento problém může jevit jinou optikou. Spíše než domněle esenciální podstata Kollárova psaní se mohou předmětem odborného zájmu stávat dějiny recepce jeho díla. Téměř dvěstěletá recepční a interpretační činnost totiž zřetelně ukázala, že jednotlivá stanoviska a soudy mohou být mnohem př́iznačnější pro recepční prostředí, případně pro interpreta, ${ }^{7}$ než pro Kollárovu tvorbu jako takovou. Již pouhý bibliografický přehled nejpříznačnějších českých a slovenských pohledů na Kollárovo dílo je dnes pro svou extenzivnost prakticky nereálný. ${ }^{8}$ Zároveň tu však v rámci literárněhistorické sebereflexe vidíme řadu pokusů vytvořit souhrnné studie, mající $\mathrm{z}$ hlediska dějin literární vědy mimořádnou výpovědní hodnotu. Autorem jedné z nejnovějších je Miloslav Vojtech, který sice zdaleka nepodává úplný přehled tématu, ale jeho studie je přesto hodnotným a neopominutelným př́spěvkem $\mathrm{k}$ rozpravě.

Vojtech nejprve seznamuje čtenáře se staršími stanovisky Jaroslava Vlčka, Pavla Bujnáka, Felixe Vodičky, Arne Nováka, Jana Jakubce, Vojtěcha Jiráta a Mikuláše Bakoše i jiných, a poté konstatuje, že se česká literárněhistorická recepce u Kollára přiklání spíše k preromantismu, zatímco slovenská spíše ke klasicismu. ${ }^{9}$ Ačkoli neproniká do hloubky rozdílu mezi českým a slovenským literárněvědným

5) Kollár v Pamětech zmiňuje návštěvu Dániela Crudyho (1735-1815), evangelického biskupa v Mošovcích roku 1803, nebot při této příležitosti vznikla jeho první slovenská báseň. Viz Kollár, Jan: Paměti z mladších let života. Spisy Jana Kollára. Díl čtvrtý. Cestopis druhý a Paměti z mladšich let života Jana Kollára sepsány od něho samého. V Praze Nákladem knihkupectví I. L. Kober, 1863, 8. kapitola s názvem První slovenské verše. Crudy, Burian, s. 108-111.

Z hlediska našeho tématu můžeme za milník považovat rovněž jeho latinskou školní báseň s názvem Deploratio presentis status Hungariae. O ní podrobněji viz: Kiss Szemán, Róbert: „Slávy dcera“, Slovenská literatúra LIX, 2012, 2, s. 89-111.

6) Kollár, Ján: Staroitalia slavjanská aneb objevy a důkazy živlů slavských v zeměpisu, v dějinách a v bájeslovi, zvláště v reči a v literatuře nejdávnějších vlaských a sousedních kmenů... Vídeň, Císařská královská dvorská a státní tiskárna 1853. 1803-1853 je navíc přesně půlstoletí.

7) Jako analogický příklad s Máchovou recepcí viz Dalibor Tureček - Veronika Faktorová: KHM 1810-2010: Dvě století české kultury s Máchou. Katalog k výstavě v Letohrádku Hvězda 29. června - 31. řínna 2010. Praha: Památník národního písemnictví 2010.

8) Ormis, Jan V.: Bibliografia Jána Kollára. Bratislava, Vydavatel’stvo Slovenskej akadémie vied, 1954. Gerbócová, Jarmila: Ján Kollár v literatúre od roku 1952. Bibliografia. Bratislava, Ústav slovenskej literatúry, 1991, strojopis s. 138.

9) Vojtech, Miloslav: „Klasicista - preromantik - romantik. Kotázke slohovotypologického zaradenia básnickej tvorby Jána Kollára v českej a slovenskej literárnej histórii“, in Vojtech, Miloslav: Literatúra, literárna história a medziliterárnost'. Bratislava, Filozofická fakulta Univerzity Komenského, 2004, s. 56-67. 
diskurzem, přesto autor tvrdí, že zmíněné dilema vede ve skutečnosti „do slepé uličky“, z níž nás může vyvést jednak uplatnění komparatistického hlediska, ${ }^{10}$ jednak přijetí a interpretační aplikace teze synkretizmu literárních směrů jako základního faktu. ${ }^{11}$ Toto tvrzení se přirozeně zakládá na komparatistickém bádání druhé poloviny minulého století a znamená určité přeformulování tradiční myšlenky národních filologií, které kromě jiných specifik mají ve zvyku charakterizovat středoevropské národní literatury ve světle domněle opožděného hospodářského, společenského a politického vývoje a následně pak jako neblahý důsledek vnímají ono příznačné mísení stylů, charakteristické také pro Kollárovu tvorbu. ${ }^{12}$ Tyto přístupy středoevropské komparatistiky - které je možné interpretovat i z pohledu postkoloniální kulturní kritiky - se přirozeně nevztahují pouze na český, ale i na mad’arský či slovenský kulturní korpus. Zmiňovanou problematiku kupříkladu ve svém díle Dějiny vývoje mad’arské literatury (A magyar irodalom fejlődéstörténete) prozíravě reflektoval již jeden z nejvýznamnějších mad’arských literárních historiků první poloviny 20. století, duchovědou inspirovaný János Horváth (1878-1961). ${ }^{13}$ Ten podobně jako jeho čeští a slovenští kolegové tvrdil, že klasicistní dědictví mad’arského osvícenství prostoupil během 19. století romantický svět citů a myšlení, ovšem takovým způsobem, který zároveň zanechal nedotčené dědictví klasicistních forem. Citujme ad illustrandum: „Pro toto - abych tak řekl - deklasicizování byla příznivá rovněž okolnost, že i básníci moderní školy - Dayka, Batsányi, Kazinczy - používali antické básnické formy a vnesli tak, následně zejména s Kölcseym a Vörösmartym, do staroklasické básnické formy moderní lyričnost. "14

10) „Zdôrazňovanie Kollárovej dominantnej »klasicistickosti« ako aj opačné tvrdenia o jeho »preromantickosti« prevažne na českej strane vedú úvahy na túto tému do slepej uličky. Ak aplikujeme na Kollárovu tvorbu komparatívne hladisko a budeme v nej hladat tie typologické prvky, ktoré sa v európskych literatúrach považujú za klasicistické a preromantické, logicky dôjdeme k záveru, že Kollárova tvorba je rovnako poplatná klasicizmu ako aj preromantizmu [...]. Vojtech, Miloslav: „Klasicista - preromantik - romantik. K otázke slohovotypologického zaradenia básnickej tvorby Jána Kollára v českej a slovenskej literárnej histórii“, in Vojtech, Miloslav: Literatúra, literárna história a medziliterárnost'. Bratislava, Filozofická fakulta Univerzity Komenského, 2004, s. 65-66.

11) „Je potrebné prijat tézu o synkretizme literárnych tendencií rôzneho druhu a rôznej kvality v tejto etape literárnych dejín.“ Vojtech, Miloslav: „Klasicista - preromantik - romantik. K otázke slohovotypologického zaradenia básnickej tvorby Jána Kollára v českej a slovenskej literárnej histórii“, in Vojtech, Miloslav: Literatúra, literárna história a medziliterárnost'. Bratislava, Filozofická fakulta Univerzity Komenského, 2004, s. 67.

12) Viz např. Sziklay, László: „Einige methodologische Fragen der vergleichenden Literaturgeschichte (Die ungarisch-slavischen literarischen Beziehungen)“, Studia Slavica, 9, 1963, s. 331-335. Fried, István: „Verspätung, Neuerung, Periodisierung in der ostmitteleuropäischen Romantik“, Studia Slavica 32, 1986, 1-4, s. 3-30.

13) Role této Horváthovy práce je zřjmá od 20. let 20. století. V roce 1924 z ní četl ukázku v literární Společnosti Kisfaludyho. Viz úvodní poznámku Jánose H. Korompayho: Horváth, János: „A magyar irodalom fejlődéstörténete“, in Irodalomtudományi Közlemények 1969, s. 349-367, poznámka na s. 349. Dostupné na http://www.epa. uz.ua/00000/00001/00261/pdf/itk_EPA00001_1969_02-03_349-367 (př́stup 29. 3. 2017).

14) Horváth, János: „A magyar irodalom fejlődéstörténete (Dějiny vývoje madarské literatury)“, in Korompay H., 
Analogický typ procesů logicky charakterizoval i nemad’arské literatury v Uhrách - jak česky píšící evangelické Slováky, tak Slováky katolické, používající různé varianty západoslovenského literárního jazyka. $Z$ katolických básníků patři k emblematickým postavám Kollárův souputník, básník-kněz Ján Hollý, který pěstoval různé klasické básnické formy a své aktuální politické i společenské frustrace, pramenící z uherského „paralelního národotvorného procesu“, ${ }^{15}$ transponoval po vzoru Vergiliova historického eposu na dějiny Velké Moravy (Svatopluk: vítazná báseň vo dvanácti zpevoch; 1833). Snad nejlepším dokladem masivní přítomnosti klasicismu v kulturním životě uherských národností je Bohuslav Tablic, který už v desetiletí rozkvětu mad’arské romantiky, tedy v roce 1832, vydal v českojazyčném přebásnění v královské univerzitní tiskárně na Budíně dílo nejznámějšího teoretika klasicismu Boileaua, pojednávající o umění básnictví. ${ }^{16} \mathrm{~K}$ uvedeným př́kladům bychom mohli přidat $\mathrm{z} 20$. a 30. let předminulého století nespočet dalších, soustřed’me se však spíše na charakter problému, který nám ony př́iklady ilustrují a ze kterého vyplývá, že k nejdůležitějším pojmům literárněhistorického nazírání ve 20. století patří synkretismus stylů, neboli jinak řečeno otázka oscilace či přechodu mezi styly.

$\mathrm{K}$ tomu, abychom se mohli dostat dál a překročili již částečně zmiňovaná konstatování dosavadní odborné literatury, potřebujeme teoretickou pomoc. Podívejme se nejprve na ty pokusy v teorii umění, které se snaží danou otázku vyřešit tak, že na hranici dvou uměleckých stylů nebo období vyznačí třetí, přechodný styl/období. Podstatou této metody je, že místo pokusu o popis složité dynamiky, probíhající mezi dvěma uměleckými paradigmatickými systémy, se do terminologického instrumentáře včlení třetí prvek, kterému se poskytne status samostatného stylového směru. Takové pokusy jsou někdy úspěšné, někdy nikoli. Mezi úspěšné kupř́kladu náležela snaha Johna Shearmana, který mezi zralou renesanci a baroko včlenil pro uchopení přechodného úseku nové období, a sice manýrizmus. ${ }^{17}$ Jenže jako se Achillovi nikdy nepodaří dostihnout želvu, tak ani tato metoda nepřinesla pokaždé vyřešení problému. Selhávání

János - Korompay Klára (eds.): Horváth János irodalomtörténeti munkái I. (Literárněhistorické práce J. H.) Budapest, Osiris Kiadó 2005, 57-452, zde s. 270.

15) Szarka, László (ed.): A modern szlovák nacionalizmus évszázada 1780-1918 - Párhuzamos nemzetépítés a multietnikus Magyar Királyságban, 1780-1918 (Století moderního slovenského nacionalismu - Paralelní národotvorné procesy v multietnickém Uherském království), Akadémiai Kiadó, Budapest 2011.

16) [Boileau, Despreaux]: Uměnj básnjřské, které we francouzském gazyku Boileau Despreaux we čtyřech zpěwjch složil, w česko-slowenský pak gazyk přeložil Bohuslaw Tablic. W Budjně, w král. universické tiskárně, 1832.

17) Shearman původní pojem manýrismu jako estetického nedostatku naplnil pozitivním obsahem: Shearman, John: „Maniera as an Aesthetic Ideal“, in The Renaissance and Manierism. Studies in Western Art. Princeton, Princeton University Press 1963, II., s. 202-208. 
„mezipojmů“ se teorie vědy pokoušela vysvětlit základním charakterem vědeckých paradigmat, ${ }^{18}$ které se v oblasti humanitních věd snažila uchopit jako proměnlivé procesy složitých systémů (polysystémy, polysystémová teorie). ${ }^{19}$ Takový přístup napomáhá profilovat interpretační prostředky moderních literárněvědných škol, které ponechávají stranou tradiční hodnotící hledisko, preferující zdánlivě homogenní základní entity před prvky hybridními, a jev přechodu naopak považují za primární formu existence literatury, čímž si mimo jiné otevírají možnost opětovného čtení a reinterpretace. $Z$ tohoto hlediska lze v našem kulturním regionu považovat za milník teoretické tvrzení Petera Zajace o literární vědě jako o synoptické mapě, ${ }^{20}$ jakož i vydání díla České literární romantično a snahu autorů o ujasnění historie př́islušného pojmu a prozkoumání možností jeho současné aplikovatelnosti. V této souvislosti Dalibor Tureček upozorňuje, že místo vzájemného překonání literárněvědných modelů pro literárněvědný diskurz je mnohem plodnějším způsobem soužití různorodých modelů. ${ }^{21}$

Vrátíme-li se ke Kollárovi, můžeme konstatovat, že pokusy o opětovné čtení a reinterpretaci jeho tvorby se daly do pohybu poté, co utichly bitevní vřavy doprovázející změnu režimů, a od počátku nového tisíciletí probíhají takřka neustále. ${ }^{22}$ Byly učiněny různé pokusy jak uchopit osobnost typu Kollára, jak vykreslit společenský, kulturní schematický systém řídící působení postavy veřejného života, ${ }^{23}$ jak umístit tuto postavu do českého a slovenského národotvor-

18) Kuhn, Thomas S.: The Structure of Scientific Revolutions. Third Edition. Chicago, The University of Chicago Press, 1996.

19) Even-Zohar, Itamar: "Polysystem Theory", Poetics Today 1990/1, s. 9-26. Zde s. 16. http://www.tau.ac.il/ itamarez/ works/books/ez-pss1990.pdf: "As with a natural system, which needs, for instance, heat regulation, cultural systems also need a regulating balance in order not to collapse or disappear. This regulating balance is manifested in the stratificational oppositions. The canonized repertoires of any system would very likely stagnate after a certain time if not for competition from non-canonized challengers, which often threaten to replace them. Under the pressures from the latter, the canonized repertoires cannot remain unchanged. This guarantees the evolution of the system, which is the only means of its preservation. On the other hand, when no pressures are allowed release, we often witness either the gradual abandonment of a system and movement to another (e.g., Latin is replaced by its various Romance vernaculars), or its total collapse by means of a revolution (overthrow of a regime or the total disappearance of hitherto preserved models, etc.)."

20) Zajac, Peter: „Literárne dejepisectvo ako synoptická mapa“, in Dalibor Tureček - Zuzana Urválková (eds.): Mezi texty a metodami, Periplum, Olomouc 2006, s. 13-22.

21) „Přiznáním nevyhnutelné plurality koexistujících modelů zároveň mizí představa literárních vývinových proměn literárněhistorického myšlení, kdy nastupující, dokonalejší varianta poznání »překonává " předcházející, již nedostačující stupeň.“ Dalibor Tureček: „Synopticko-pulzační model českého literárního romantična“, in Tureček, Dalibor a kol. (eds.), České literární romantično. Synopticko-pulzační model kulturního jevu. Host, Brno 2012, s. 94.

22) Kiss Szemán, Róbert: „Jan Kollár, velký kreátor“, Grundlage II. Emblematický národopis: zeměpis, národopis, přírodopis a zoologie. Slovanský přehled 91, 2005, 557-563; Jan Kollár: Slávy dcera. Báseň lyricko-epická v pěti zpěvích. Putna, Martin C.: Překlad a výklad Slávy dcery z panslavistického mýtu do kulturní historie. Academia, Praha 2014.

23) Macura, Vladimír: Znamení zrodu. České národní obrození jako kulturní typ, Praha, H \& H 1995 (II. bővített kiadás). Kiss Szemán, Róbert: Slovanský Goethe v Pešti. Ján Kollár a národní emblematizmus středoevropských Slovanů. Akropolis, Praha 2014. 
ného procesu. ${ }^{24}$ Zároveň se však zdá být potřebné začlenit do výzkumu taková další literárněvědná hlediska, která hledají odpovědi na změny recepčního horizontu, na utváření kulturního kánonu, ${ }^{25}$ nebo na otázky související s mocí. Výzkum, směřující v budoucnosti úhrnnému, metodologicky novému zhodnocení Kollárovy recepce a zahrnující rovněž komparatistická hlediska, by měl s ohledem na výše uvedené výsledky a metody hledat odpověd’ i na otázku, kdy a proč se tolik odlišuje české a slovenské přijetí a proč ta či ona literárněvědná tradice preferovala začlenění Kollárovy tvorby do kulturního kánonu klasicismu nebo romantismu.

Přejěme ale nyní se od dějin recepce $\mathrm{k}$ pohledu na kulturní prostor, v němž Kollárova tvorba vznikala. $Z$ mé pozice se kromě české a slovenské literární historie jeví jako důležitý faktor kulturního zázemí rovněž uherská latinská vzdělanost a klasicismus, které svými specifiky zásadně určily nejen Kollárovu tvorbu, ale i způsob její uherské (a v rámci toho slovenské) recepce.

\section{Specifika neo-latinské, školní latinské a klasicistní literatury $v$ Uhrách na přelomu 18. a 19. století}

Abychom se mohli úspěšně vypořádat s popisem přibližujícím uherský klasicismus jako umělecký směr, musíme nejdříve přijmout některá fakta. Jedním $\mathrm{z}$ nich, kterému se nebudu podrobněji věnovat, je hlavní myšlenka monografie Europäische Literatur und lateinisches Mittelalter Ernsta Roberta Curtia, že totiž latinský fenomén byl průběžně přítomen a od raného středověku formoval evropskou kulturu. ${ }^{26}$ Druhá premisa zní, že nositelem této kultury byla především klasická latina, která sice existovala v různých jazykových variantách, avšak rozhodující měrou určovala evropské kultury, včetně kultur střední Evropy. Třetím

24) Matus, László: A Pesti Szlovák Evangélikus Gyülekezet (Evangelický sbor Slováků v Pešti), Piliscsaba, Pázmány Péter Katolikus Egyetem Bölcsészettudományi Kar, 2000, diplomová práce, obor historie. Matus, László: „Ján Kollár és a pesti szlovák evangélikusok asszimilációjának problémája a 19. század húszas éveiben“ (J. K. a problém asimilace pešťských slovenských evangelíků ve 20. letech 19. století), in Világtörténet, 2000, č. 2, s. 61-73.

25) V souvislosti s tímto tématem lze jen těžko opomenout pojem kánonu jako kulturní ochrany zájmů. Místo jeho podrobnějšího rozboru zde pouze odkazujeme na studii Institutional Control of Interpretation od Franka Kermode. Salmagundi 43, 1979, Winter, s. 72-86.

26) Curtius, Ernst Robert: Europäische Literatur und lateinisches Mittelalter. A. Francke AG-Verlag, Bern, MCMXLVIII. Česky: Evropská literatura a latinský středověk. 
historickým faktem je, že latina byla na zlomu 18. a 19. století a ještě i mnohem později v Uhrách nejen úředním jazykem, ale zároveň i dorozumívacím prostředkem mezi jednotlivými národy a národnostmi. Teprve zákonný článek 1836/III. ${ }^{27}$ povolil v soudnictví a na sněmu na úkor dosud obligatorní latiny užívání mad’arského jazyka a článek $1844 /$ II ${ }^{28}$ ji učinil povinnou ${ }^{29}$ a povinná se stala i výuka mad’arštiny na středních školách. V duchu výše uvedených konstatování bych rád ukázal kulturní obraz Uher druhé poloviny 18. století, kdy jsme svědky toho, jak se v předsíni klasicismu hemží početný a národnostně různorodý zástup těch, kteří praktikují latinský jazyk a literaturu a podle svého vzdělání a kulturních zvyklostí aplikují tento kulturní poklad rozdílným způsobem. Pro názornost můžeme ty, kteří latinský jazyk a literaturu 18. století pěstují a latinsky čtou, rozdělit na tři skupiny.

3.1. V předsíni klasicismu přešlapují ti znalci a čtenáři antických autorů, kteří na tuto kulturu nahlížejí renesančními a barokními brýlemi. Tomuto klasickému řeckému a římskému kulturnímu korpusu, jeho struktuře a složení, se už mnozí věnovali, a protože se v této věci nepovažujeme za dostatečně kompetentní a navíc se bezprostředně netýká našeho tématu, přenecháme její výzkum klasickým filologům. Avšak na tomto klasickém kánonu stavěla tak zvaná neo-latinská literární kultura, o kterou se v mnohých relacích opíral (i) středoevropský klasicismus. Počátek mad’arského osvícenství klade literární věda do roku 1772, kdy vyšlo drama Ágisova tragédie Györgye Bessenyeiho. Děj situovaný do starověké Tróje zachycuje tragédii Ágise, mladého knížete, který se vzbouří a zorganizuje vzpouru proti králi Leonidovi. Bessenyei, jenž zpracovává téma dobrého a užitečného panování, staví drama na generačním konfliktu a vytváří tak parafrázi oslavující vládu Marie Terezie, které jako člen uherské dvorní gardy toto dílo věnoval. Bessenyei však zdaleka není autorem pouze tohoto dramatu s klasicistními prvky. O pět let dříve publikoval své první drama Tragédie Ladislava Hunyadiho (1767), jejímž bezprostředním předchůdcem bylo latinské školské drama Ladislaus Hunyady z pera neznámého jezuity. Literární vědec László Szörényi v této souvislosti přesvědčivě prokázal, jakým způsobem pozměnil Bessenyei strukturu latinského školského dramatu, úlohy postav a povahu výpovědi, aby z obsahového hlediska odpovídaly očekávání vídeň-

27) https://1000ev.hu/index.php?a=3\&param=5148. Staženo: 2016. 01. 16. 16: 48

28) https://1000ev.hu/index.php?a=3\&param=5255. Staženo: 2016. 01. 16. 16: 54.

29) Proti tomu Kollár na všech možných fórech protestoval. Mimo jiné aby musely být matriky a záznamy peštské evangelické církve psány mad’arsky. 
ského dvora, po formální stránce pravidlům klasicistního dramatu, jazykově pak mad’arskému čtenáři. ${ }^{30}$ Individuální způsob propojení Bessenyeiho díla se zmíněným latinským školským dramatem následně otevřel cestu k vykreslení literárního procesu jako možného obecného modelu, který lze uplatnit nejen na mad’arskou kulturu, ale i na jiné uherské literatury.

Právě zmíněný proces se přitom přirozeně manifestoval i mimo drama, $\mathrm{v}$ jiných žánrech. Dělo se tak i v dobově mimořádně prestižním žánru, jímž byly ve středoevropských literaturách 19. století eposy s národní tematikou. V mad’arském kontextu se tu navazovalo na epos barokní, jehož př́klady mohou být díla Mikuláše Zrinského Obléhání Szigetu (1651) ${ }^{31}$ či Istvána Gyöngyösiho $S$ Martem rozmlouvající muráňská Venuše (1664). ${ }^{32}$ Více než stoletou mezeru mezi nimi a eposy psanými v národních jazycích, nacházejícími se již na rozhraní mezi národním klasicismem a romantismem, jakými byly Vörösmartyho Útěk Zalánův (1824), Hollého Svatopluk (1833), vyplňují eposy latinské. Tyto neo-latinské eposy psali převážně uherští jezuité, kteří sice byli prostřednictvím italské jezuitské provincie v kontaktu s italskou kulturou, avšak při volbě témat preferovali národní charakter, neboli opěvovali mad’arské kmeny a jejich příchod do nové, uherské vlasti. Italská neo-latinská kultura přitom měla rozhodující vliv nejen na dramatickou, epickou, ale i na lyrickou tvorbu duchovního života v Uhrách osmnáctého století.

$\mathrm{Na}$ tomto poli sehráli důležitou roli uherští členové Accademia dell'Arcadia. Významnou součástí jejich literární činnosti byla vzájemná korespondence a další aktivity, které přispívaly $\mathrm{k}$ rozvoji kulturních vztahů. Accademia dell'Arcadia byla založena v Rímě roku 1689 a ve své původní formě existovala do roku 1768. Značnou mírou přispěla $\mathrm{k}$ obnově italské poezie. $\mathrm{Z}$ uherských členů Akademie bych v prvé řadě zmínil arcibiskupa z Kalocsi, o kterém píše i Ján Kollár ve Slávy dceři, a tím nám dává živý př́iklad toho, že neo-latinští literáti byli známí i v prvních desetiletích 19. století. Jedná se o Ádáma Patatiche (1717-1784), jenž podle pravidel Accademie dell'Arcadia přijal latinské jméno Syrasius Acrotophorius. ${ }^{33}$ Patatich za svého biskupského působení ve Varadínu umožnil činnost dvorního divadla, později jako arcibiskup v Kalocsi vyvíjel

30) Szörényi, László: „Ismeretlen latin jezsuita dráma Hunyadi Lászlóról (Neznámé latinské jezuitské drama o Ladislavu Hunyadim)“, in týž: Studia Hungarolatina. Tanulmányok a régi magyar és neolatin irodalomról (Studie o staré mad’arské a neo-latinské literatuře), Kortárs Kiadó, Budapest 1999, 84-96.

31) Epos Mikuláše Zrinského vyšel poprvé ve Vídni r. 1651 jako součást sbírky Adriai tengernek szirénája (Pěvec Jaderského moře).

32) Epos (epithalamium) Istvána Gyöngyösiho vyšel poprvé r. 1664 v Košicích. Text víz: http://mek.oszk. hu/06000/06075/html/ Staženo: 7. 4. 2007. 12:01.

33) Szörényi, László: „Latin nyelvű Árkádia a tizennyolcadik századi Magyarországon (Latinská Arcadia v Uhrách 
čilou básnickou činnost. V jeho rukopisné sbírce Annalecta poetica najdeme básně publikované i nepublikované. Ján Kollár ho však ve svém díle nezmiňuje z důvodu této kulturně-organizační činnosti, nýbrž proto, aby ho nechal přijít do slovanského pekla, nebot arcibiskup prý nechal vysázet rány holí těm Srbům, kteří veřejně používali svůj rodný jazyk. Kromě Patatiche bychom mohli jmenovat ještě mnoho autorů, kteří byli předobrazy uherského klasicismu z přelomu 18. a 19. století. Jmenujme tedy v této souvislosti alespoň piaristického řeholníka Konstantina Halápyho, jehož svazek obsahující bajky (Apologorum Moralium Libri VI, 1747) je zakončen básní, popisující pestře vykreslené hrůzy antického podsvětí, a je tedy jakýmsi mostem mezi pekly Danta a Kollára. ${ }^{34}$ Uherská piaristická provincie se do značné míry utvářela s polskou pomocí, proto bylo pro první generaci piaristů typické pěstování barokního stylu, označovaného jako „stylus polonicus“. Halápy je jedním z autorů, kteří se tomuto stylu vzdalují a přiklánějí se ke světlu klasicismu. ${ }^{35}$ Třetím autorem neo-latinské literatury je piarista Márk Koricsányi (1705-1752), který svou básní popisující zkázu země a kultury přispěl k vykreslení pomyslné mapy pradávných motivů, jak se jeví v literatuře počátku 19. století. ${ }^{36}$ Udržel totiž při životě topos, jehož jednou z novodobých realizací je Kollárova školská báseň Deploratio presentis status Hungariae a později na to navazující Předzpěv ke Slávy dceři z roku $1824 .{ }^{37}$ V dějinách uherské neo-latinské literatury učinil jeden z nejdůležitějších kroků směrem ke klasicismu Norbert Conradi (1718-1785). Na změnu literárního vkusu ukázal i vydáním básní Jana Pannonia, latinsky píšícího uherského poety období renesance a humanismu, a z antické literární tradice tak oživil mimo jiné lyrický epigram. ${ }^{38}$ Nejznámějším uherským neo-latinským básníkem 18. století byl nepochybně János Krizosztom Hannulik (1745-1816) ${ }^{39}$, jenž byl současníky nazýván novým Horatiem. Podle tvrzení Lászlóa Szörényiho „následoval ve svých horatiovských imitacích především M. K. Sarbiewskiho; od pol-

18. století) “, in týž: Studia Hungarolatina. Tanulmányok a régi magyar és neolatin irodalomról, Kortárs Kiadó, Budapest 1999, 121-133.

34) Viz Szörényi, László: „Latin nyelvú Árkádia a tizennyolcadik századi Magyarországon“, in týž: Studia Hungarolatina. Tanulmányok a régi magyar és neolatin irodalomról, Kortárs Kiadó, Budapest 1999, 121-133. K tématu s. 124-125.

35) Szörényi, László: „Neolatin lírai költészet a XVIII. századi Magyarországon“, in týž: Studia Hungarolatina. Tanulmányok a régi magyar és neolatin irodalomról, Kortárs Kiadó, Budapest 1999, 134-146. O Halápym 138-139.

36) Viz Szörényi, László: „Latin nyelvü Árkádia a tizennyolcadik századi Magyarországon“, in týž: Studia Hungarolatina. Tanulmányok a régi magyar és neolatin irodalomról, Kortárs Kiadó, Budapest 1999,121-133. O Koricsányim na s. 125.

37) O tom jsem psal podrobněji: Kiss Szemán, Róbert: „Slávy dcera“, Slovenská literatúra LIX, 2012, s. 89-111.

38) Szörényi, László: „Neolatin lírai költészet a XVIII. századi Magyarországon“, in týž: Studia Hungarolatina. Tanulmányok a régi magyar és neolatin irodalomról. Kortárs Kiadó, Budapest 1999, 134-146. O Conradim na s. 140.

39) Szinnyei, József: Magyar írók élete és munkái. http://mek.oszk.hu/03600/03630/html/h/h07681.htm Staženo: 4. 7. 2017. 12:08. 
ského básníka převzal zejména nový přístup, na základě kterého nahrazoval římské historické prvky národními. Tak se mohl Hannulik stát jedním z prvních významných předchůdců mad’arsky psané romantické lyriky: oslava časů minulých, pranýřování dobové pohodlnosti a zbabělosti, tón požadující národní obrození, to vše se objevuje i u největšího básníka mad’arského klasicistně-preromantického zaměření, Dániela Berzsenyiho“. ${ }^{40}$

Pojetí, podle kterého neo-latinská literatura jako jeden z precedentů klasicismu zajištuje kontinuitu literárního vývoje, je v mad’arské literární historii poměrnou novinkou. Začalo se objevovat v době uvolňování komunistické diktatury v 70 . a 80. letech dvacátého století a šíře pak bylo akceptováno v ovzduší svobodného vědeckého výzkumu po roce 1989. Představitelé literární vědy předchozího období se navzdory své erudici zasazovali o to, aby byla tato alteritní literatura (praveno s Jaussem ${ }^{41}$ ) jako výtvor církevní ideologie vyjmuta $z$ dějin národních hnutí 19. století. Jeden z významných představitelů této školy, Antal Wéber, píše ve svém díle Literární tendence, s odstupem (Irodalmi irányok, távlatból) o výše pojednávaném vztahu neo-latinské literatury ke klasicismu takto: „A zde můžeme ponechat stranou druhořadé jevy, fakt erudice dosvědčující znalost antické kultury (což je ostatně zastaralé hledisko), latinsky psanou krásnou literaturu v Uhrách a jiné podobné aspekty, jakkoli nejsou bez zajímavosti.“42 Textostředně zaměřený výzkum literatur střední Evropy přelomu 18. a 19. století ovšem tvrzení Wébera, jakož i dalších, dobové ideologii se podřizujících badatelů, jednoznačně vyvrátil. Argumentem se tu stala kupříkladu analýza a interpretace jednoznačných strukturálních shod v oblasti toposu, které podnikli Andor Tarnai a Imre Mihály, ${ }^{43}$ případně výzkum s nimi spojených středoevropských souvislostí, jaký jsem podnikl na materiálu látky „nářek Slávie“. ${ }^{44}$

40) Szörényi, László: „Neolatin lírai költészet a XVIII. századi Magyarországon“, in týž: Studia Hungarolatina. Tanulmányok a régi magyar és neolatin irodalomról, Kortárs Kiadó, Budapest, 1999, 134-146. O Hannulikovi na s. $140-141$.

41) Robert Jauss, Hans: Alterität und Modernität der mittelalterlichen Literatur. München, Fink 1977.

42) Wéber, Antal: Irodalmi irányok, távlatból. Fejezetek a felvilágosodás és a reformkor irodalmának történetéból (Literární tendence, s odstupem. Kapitoly z dějin literatury osvícenství a doby reforem), Szépirodalmi Könyvkiadó, Budapest 1974, s. 31.

43) Tarnai, Andor: Extra Hungariam non est vita... (Egy szállóige történetéhez) (K dějinám jednoho okřídleného rčení), Akadémiai Kiadó, Budapest 1969, (Modern Filológiai Füzetek 6). Týž: „A toposzkutatás története“ (Dějiny výzkumu toposu), in Literatura 1975/1, s. 66-73. Mihály, Imre, „Magyarország panasza“. A Querela Hungariae toposz a XVI-XVII. század irodalmában (Topos Querela Hungariae v literatuře 16. a 17. století), Kossuth Egyetemi Kiadó, Debrecen 1995.

44) Kiss Szemán, Róbert: „Od nářku Uher k nářku Slavie v díle Jana Kollára“, in Vyčichlo, Jaroslav - Viktora, Viktor (eds.): Jeden jazyk naše heslo bud' IV. Český romantismus - jiskření a záblesky, Plzeň, Spolek divadelních ochotníků v Radnicích - Studijní a vědecká knihovna Plzeňského kraje, 2007, s. 157-170. 
3.2. Podobná situace byla i v oblasti školské latinské vzdělanosti, kterou mad’arská literární historiografie označuje specifickým, jednoznačně pejorativním termínem „deákosság“, neboli „studentská latina“. Školní výuka přelomu 18. a 19. století ale tento druh vzdělanosti nepovažovala za pouhý doplňkový prvek, nýbrž v něm viděla nejdůležitější pedagogický prostředek, umožňující předat středoškolákům stylistické ideály a důležité obsahové prvky klasicismu. Právě proto ani zde - podobně jako u neo-latinské literatury - př́liš neobstojí následná konstatování, degradující školní latinu: „Na základě formálně-tematických znaků si tak zvaní ,studentští latiníci' mimoděk přímo říkají o přiřazení $\mathrm{k}$ tomuto klasicizujícímu směru. Avšak tento specifický jev, jakkoli by to bylo evidentní, sem nemůžeme zařadit. Nepatří sem především proto, nebot' se v něm projevuje tradičně-feudální vzdělanost, onen druh latinské vzdělanosti, který je v této starobylé formě přežitý a zastaralý. Ještě podstatnější je však okolnost, že společenský faktor nespojuje tuto vzdělanost s pokrokovými (měštanskými, občanskými) životními ideály, ačkoli citování věčně platných principů klasiků, vzpomínání ctností (virtus) a jiných morálních hodnot, přítomnost antických motivi̊ a rekvizit - od doby renesance prvků společného kulturního pokladu, je koneckonců společné s dobovými klasicistními díly, která nám ,studentské latinské básně připomínajij." ${ }^{45}$ Autor předchozího výroku, Wéber, ještě poznamenává, že se vyznavači těchto idejí nehodili pro přesazení moderních klasicistních idejí do vernakulárního jazyka ani kvůli svému církevnímu účelu. Za jejich jedinou zásluhu považuje zavedení antického metra. ${ }^{46}$ Některým sociologickým souvztažnostem těchto tvrzení musíme dát samožrejmě prostor, zároveň je však musíme oddělit od konstatování vyplývajících z ideologicky ovlivněné marxisticko-komunistické literární vědy a poukázat na to, že proces kulturně-literárního dědictví podléhal i na přelomu 18. a 19. století jiným zákonitostem.

K tomu, abychom si vytvořili správný obraz o vztahu básníků, spisovatelů, organizátorů literárního a národního života obou vrstev, tedy „studentské latiny“ a vyšší kultury, je nasnadě, že se musíme opět obrátit k pramenům. Jedním z důležitých zdrojů popisujících vztahy panující v Uhrách konce 18. století je i Kollárem často citované dílo Statistik des Königreichs Ungern od Martina von Schwartnera ${ }^{47}$ Statistika představuje ve své době žánr, který poskytuje poměrně komplexní obraz o dané zemi. Schwartner podává zajímavý popis vztahu

45) Wéber, Antal: Irodalmi irányok, távlatból. Fejezetek a felvilágosodás és a reformkor irodalmának történetéböl, Szépirodalmi Könyvkiadó, Budapest 1974, s. 32.

46) Wéber, Antal: Irodalmi irányok, távlatból. Fejezetek a felvilágosodás és a reformkor irodalmának történetéböl, Szépirodalmi Könyvkiadó, Budapest 1974, s. 33.

47) Schwartner, Martin von: Statistik des Königreichs Ungern. Ein Versuch, Pest, M. Trattner 1798; 2. vydání: Schwart- 
uherské kultury a „studentské latiny“: „Člověk neví, má-li se smát nebo plakat, když vidí, že i dnes nutí se značnou horlivostí do latinské gramatiky dítě mad’arského rolníka, které dnes ovládá deklinace a konjugace a které možná už zítra povolají zpět k pluhu a k dobytku, na celý život." ${ }^{\text {"8 }}$ Podle autora tedy školská výchova nezprostředkovala znalosti potřebné k praktickému životu, respektive trpěla absolutizováním obsahů, vhodných snad pro výchovu církevní i světské inteligence, ale nikoli pro populaci jako celek. Na druhé straně ovšem latinská vzdělanost nebyla jednoduše jen nějakou zděděnou a mechanicky tradovanou záležitostí, nýbrž podstatným konstitutivním prvkem, utvářejícím a manifestujícím jednotu Uher (tzv. povědomí hungarus). Právě v této souvislosti můžeme rozumět Kollárovu studentskému povzdechu, zaznamenanému v jeho Pamětech: „Ač právě Šulek velmi moudře mnohé užitečné nauky v mateřském jazyku pro školy sepsal a nás v nich cvičil, které já až posavád čistě přepsané na památku zachovávám: nic méně však i v latině tak nás cvičeno, že v srdci mém nejednou ta dětinská žádost a myšlénka povstala, jako by to dobře bylo, kdyby všecky jiné řeči zmizely a všichni lidé jen latinsky mluvili.“" ${ }^{49}$ Školní výuka latiny ale především na přelomu 18. a 19. století dala dorůstající literární generaci do rukou takové prostředky a vzory, od jejichž obrovského vlivu se klasicistní generace dokázala odpoutat jen stěží, romantická generace pak byla nucena postavit se proti ní, aby dokázala definovat sama sebe.

Hlavním pramenem klasicistního vědění přitom byla v Uhrách francouzská díla 17. století, tradovaná zpravidla v konvolutech s koncovkou názvu „-ana“. Tyto sbírky dostávaly názvy podle jmen těch, kteří je sestavovali (Gilles Ménaga - Menagiana, Patiniana atd.). Obsahem sbírek jsou nejrůznější úvahy, výtahy, věnující se mimo jiné takovým tématům, jako např. Bídné uznání literátů nebo Lepší ctnostný život, než bezectná smrt (Honores mutant mores, raro in meliores) aj. V tomto žánru publikoval své Omniarium i básník-jezuita Ferenc Faludi, člen Accademia dell’Arcadia. Jeho obsah tvořily kromě lyrických děl i výtahy a osnovy školských studií. $Z$ těchto sbírek také pocházejí učené a moudré (grave, savant) úlohy (propositio), které měli studenti zpracovat formou básně nebo prózy. $Z$ toho vyplývá, že básnická témata se - $\mathrm{v}$ duchu neměnných

ner, Martin von: Statistik des Königreichs Ungern, Gedruckt mit Königl, Univerisitäts-Schriften, Zweyte vermehrte und verbesserte Auflage, Ofen 1809.

48) Viz Szauder, József: Az iskolás klasszicizmus. (Školní klasicismus), in týž: Az éj és a csillagok. Tanulmányok Csokonairól (Studie o Csokonaim), Akadémiai Kiadó, Budapest 1980, s. 36-56. Mad’arský překlad na s. 37-38. Odkaz: „Schwartner, Marton (sic!): Statistik des Königreiche (sic!) Ungern. Pest 1809. III. Theil. 429. 1.“

49) Kollár, Jan: „Paměti z mladších let života“, in Spisy Jana Kollára. Díl čtvrtý. Cestopis druhý a Paměti z mladších let života Jana Kollára sepsány od něho samého, Praha, I. L. Kober 1863, s. 95. 
učebnic - pohybovala nejen v dobře ohraničitelném kruhu obecnosti, ale ti, kteři je připravovali (praeceptor) si seznam propozic zřejmě navzájem předávali, takže nanejvýš docházelo jen $\mathrm{k}$ určitým obměnám, ale mezitím se v podstatě staly všeobecným pokladem, který předávali svým nástupcům. ${ }^{50}$ Podle tvrzení mad’arského literárního historika Józsefa Szaudera ovšem vznikaly na tato témata nejen výtvory méně invenčních literátů, ale zásadní paralely s latinskými propozicemi vykazují třeba i první básně autora známého porušováním klasické formy, Mihálye Vitéze Csokonaiho. ${ }^{51}$

Aplikaci těchto pravidel domněle „primitivního klasicismu“ (řečeno termínem Szauderovým) je zároveň potřeba nahlédnout s pomocí jednoho z nejdůležitějších tvưrčích psychologických hledisek, které vznikající dílo nepovažuje za dokonalou, jedinečnou a neopakovatelnou věc. Dílo je čímsi, co usiluje o dokonalost, neboli jedná se o určitou momentku zhotovenou v některé fázi tvůrčího procesu. $Z$ toho rovněž vyplývá, že myšlenkové i tvárné výsledky starších uměleckých pokusů, vzniklých $\mathrm{v}$ dřivějších fázích, jsou použitelné při vzniku nových děl: konkrétně je možné přepisovat a přepracovávat méně podařené části, dobře napsané části je možné převzít a v nových dílech znovu použít. Pro badatelskou praxi tento př́istup znamená, že je velmi obtížné rekonstruovat chronologii. Při psaní básní je uplatňován princip klasicistní korekce, neboli dílo je přepisováním zdokonalováno. $Z$ tohoto principu vyplývá nejen možnost, ale i povinnost napodobování. $V$ tomto tvưrčím procesu představuje adaptace takový přistup, který v určitých jazykových kulturách zaplňuje některé z prázdných míst. Aplikujeme-li všechny tyto principy, vědecké a umělecké tvůrčí způsoby např. na Kollárovu tvorbu jako na celek, nezbývá nám než uznat, že nám Kollár může posloužit jako jeden z nejtypičtějších př́ikladů klasicistního přístupu, čerpajícího z nejrůznějších zdrojů.

Jelikož na lekcích poetiky považovali poezii za formu, pomocí níž je možné naučit potřebné věci i ty, kteří by si jinak nedokázali patřičné znalosti osvojit, ${ }^{52}$ není vůbec překvapující, že v této době byly básně doprovázeny vysvětlivkami, poznámkami pod čarou, nebo k nim byly připojovány prozaické úvahy. Analogický úzus můžeme najít i u Kollára v jeho Přimětcích čili vysvětlivkách ke Slávy dceři. Jiný oblíbený postup představuje dobová myšlenka „učení pomocí pře-

50) Na něj odkazuje Szauder, József: „Az iskolás klasszicizmus“, in týž: Az éj és a csillagok. Tanulmányok Csokonairól, Akadémiai Kiadó, Budapest 1980, 36-56. Citát na s. 19.

51) Szauder, József: „Az iskolás klasszicizmus“, in týž: Az éj és a csillagok. Tanulmányok Csokonairól, Akadémiai Kiadó, Budapest 1980, 36-56. Témata viz na s. 48.

52) Viz Szauder, József: „Az iskolás klasszicizmus“, in týž: Az éj és a csillagok. Tanulmányok Csokonairól, Akadémiai Kiadó, Budapest 1980, s. 36-56. Téma viz na s. 43. 
kladu“ (translatio studiorum), které vděčíme za četné adaptace nebo překlady a za úctu k nim; ačkoli se tento didaktický postup nevztahuje přímo ke Kollárovi, je př́iznačný jak pro mentalitu doby, tak pro mnohé, hojně překládající Kollárovy souputníky. ${ }^{53}$

3.3. Výše popsanými způsoby splývaly uherská neo-latinská i studentská latinská kultura a vzdělanost co možná nejpřirozenějším způsobem se západoevropským, původně francouzským klasicismem, který se do našeho regionu dostával prostřednictvím německého vlivu. Nejedná se nám tu ale o obecné principy, nýbrž o jednotlivý případ Jana Kollára. Jako výchozí bod nám přitom poslouží Kollárova návštěva Johanna Wofganga von Goetha. Kollár se do přijímacího salónu velkého mistra německého klasicismu a rané romantiky dostal jako student evangelické teologie $\mathrm{v}$ Jeně. Jak o tom referuje $\mathrm{v}$ Pamětech, našel ve výmarském salonu nejen klasicistního vědce, ale především krále romantických básníků, který svou pozornost vůči hostům projevil živým zájmem o německý překlad slovenských/slovanských lidových písní, který mu Kollár slíbil. Určité intelektuální napětí ale vzbuzovala již skutečnost, že Kollár navzdory uherskému původu zdůrazňoval svoji slovenskou/slovanskou národnostní příslušnost. ${ }^{54}$ Jelikož vzpomínky a paměti nejsou jen objektivizujícím prostředkem uchování paměti, ale jejich prostřednictvím přichází ke slovu i subjekt vzpomínajícího/vypravěče, nemůžeme Kollárův referát o setkání s vůdčí osobností německých básníků považovat za historický dokument, nýbrž za spis sloužící vlastní sebe-reprezentaci. ${ }^{55}$ Zvláště důležité přitom je, že se jedná o projekci člověka nacházejícího se ve fázi rané dospělosti ${ }^{56}$ a zároveň o pokus ztotožnit se s rolemi Goetha

53) Szörényi, László: „Latin nyelvű Árkádia a tizennyolcadik századi Magyarországon“, in týž: Studia Hungarolatina. Tanulmányok a régi magyar és neolatin irodalomról, Kortárs Kiadó, Budapest 1999, 121-133. K tématu viz s. 124.

54) Kollár, Jan: „Paměti z mladších let života“, in Spisy Jana Kollára. Díl čtvrtý. Cestopis druhý a Paměti z mladších let života Jana Kollára sepsány od něho samého. V Praze Nákladem knihkupectví: I. L. Kober, 1863, s. 247-248.

55) Paul de Man píše v souvislosti se životopisem toto: „[...] životopis, který se snaží napravit pomíjivost [...] stejnou měrou ochuzuje a stává se beztvarým, jako nakolik napravuje. Životopis zakrývá, že způsobuje deformaci duchovního vzhledu“ (de Man, Paul: „Az önéletrajz mint arcrongálás“ (Životopis jako deformace vzhledu), Pompeji, 1997, č. 2-3. s. 93-107. Mad’arský překlad Fogarasi György. V elektronické podobě: http://www.irodalomelmelet.atw. hu/deman.pdf. Staženo: 2016. 4. 20. 16:33. Anglicky: „Autobiography as De-facement“, MLN 94, 1979, 5 (Dec.), Comparative Literature, s. 919-930).

K současnému stanovisku slovenské literární vědy v otázce autobiografičnosti viz Ivana Taranenková (ed.): Možnosti autobiografickosti, Ústav slovenskej literatúry SAV - Pedagogická fakulta Trnavskej univerzity, Bratislava 2013.

56) Podobných scén, majících funkci projekce a sebe-reprezentace, najdeme z jeho tvorbě nespočet, jejich shromáždění a rozbor je úkolem dalšího bádání. Zde však uvádíme jen úvodní dialog prvního cestopisu s inspektorem evangelické církve Károlyem Zaym a na začátku druhého cestopisu popsanou návštěvu u smrtelné postele Jerneje Kopitara - Cestopis obsahujíci cestu do Horní Italie a odtud přes Tyrolsko a Baworsko, se zvláštním ohledem na slawjanské žiwly roku 1841. konanau a sepsanau od Jana Kollára S Wyobrazeními a Přilohami též i se Slowníkem slawjanských umělcůw wšech kmenůw od neystarších časůw k nynějšímu wěku, s krátkým žiwotopisem a udáním znamenitějších, zwláště národních, 
jako mistra v literatuře, veřejném životě, jako cestovatele, vědce nebo dvořana. Kollárovo „grandiózní self“ je následně utvářeno souhrnem vzorů chování spojených s těmito jednotlivými rolemi a využívá psychologických schémat, jako nutného prostředku k uchopení moci neboli k řízení svého okolí. ${ }^{57}$ Mezi rolemi lze samozřejmě vypozorovat určitý posun v preferencích: na počátku Kollárovy životní dráhy dominovala básnická role, postupně se prosazuje role aktivisty $\mathrm{v}$ církevním a veřejném životě, později dominuje role cestovatele a vědce, až nakonec jeho životní dráhu uzavírá sebe-reprezentace dvořana. V souvislosti s rolí básníka můžeme ve shodě s většinou odborné literatury konstatovat, že je pro ni charakteristická oscilace mezi klasicismem a romantismem. První verze Slávy dcery z r. 1824 může být jednak školním př́ikladem lpění na klasických formách, ale i příkladem romantické básnické atitudy, uspořádání krajiny, vztahu k dějinám, ${ }^{58}$ přičemž toto napětí je pro estetickou hodnotu díla přínosem. Období mezi vydáními z roku 1824 a 1832 má zásadní význam nejen kvưli změnám $\mathrm{v}$ rozsahu a struktuře díla, ale i $\mathrm{z}$ toho hlediska, že autor zjevně v mezidobí mezi oběma vydáními nechtěl zásadně měnit povahu své tvorby, jinak řečeno učinit zadost stále silnějším romantickým recepčním očekáváním. Kollár je tehdy už zralým třicátníkem, v jehož životě si církevní-veřejně činná část osobnosti bere stále větší díl a této církevní-veřejně činné roli grandiózního „self“ přizpůsobuje rovněž básnické prostředky patřící roli předchozí. S ústupem básnické role Kollár postupně rezignuje na možnost změny literárního jazyka a celkové koncepce literární tvorby, která by v důsledku vytvářela předpoklad afirmace ke slovenské romantické generaci. Tento krok dokázali udělat až mladší slovenští literáti, v neposlední řadě L’udovít Štúr. Kollár však postupně ustrnul v uherské (slovenské) klasicistní lyrické tradici a již za svého života se stal emblematickou postavou tohoto panteonu. Paralelně s tím se i český horizont vkusu přirozeně posunul směrem $\mathrm{k}$ romantismu a $\mathrm{v}$ Kollárovi proto viděl pouze geniálního

wýtworůw, Pešṫ 1843. Tiskem Trattner Károlyiho. VI-VIII; Spisy Jana Kollára. Díl čtvrtý. Cestopis druhý a Paměti z mladších let života Jana Kollára sepsány od něho samého S Podobiznou Jana Kollára a snímkem vlastnoručního jeho psani, Praha: I. L. Kober, 1863, s. 3-4.

57) Bánki, György: A legnagyszerübb könyv a nárcizmusról (Jedinečná kniha o narcismu), Ab Ovo Kiadó, místo vydání neuvedeno 2016.

58) „V Kollárově konceptu minulosti je romantický především vypjatý citový postoj, který je k dějinám i př́tomnosti zaujímán. Hned v druhém verši »Předzpěvu« se objevuje expresívní protiklad kolébky a rakve, duchové dávných hrdinů procházejí za úpěnlivého sténání zříceninami současnosti a postoj k úpadku vlasti je přirovnáván k pláči nad kostmi mrtvé milenky. Hlavnými rozlišujícími příznaky pro nás tedy budou: mystizující př́iklon k ranému středověku, akcent na motivy vypjaté citovosti, užití charakteristických romantických motivů, forma sonetu, respektive sonetového věnce, / intertextuální souvislost s dobově prestižními romantickými díly německé provenience, stejně jako s Byronem“ (Dalibor Tureček: „Synopticko-pulzační model českého literárního romantična“, in Tureček, Dalibor a kol.: České literární romantično. Synopticko-pulzační model kulturního jevu, Host, Brno 2012, s. 108-109). 
tvưrce, barda zániku západního slovanství a apoštola československé jazykové jednoty, takže se mu v českém kulturním kánonu 19. století postupně dostávalo místa zcela odlišného od jeho slovenské pozice.

3. 4. V další části se nemám $v$ úmyslu věnovat lyrické roli a jejím realizovaným formám, ale soustředím se v duchu výše vykreslených životních rolí na jiné části Kollárovy tvorby. Avšak vzhledem k tomu, že vědecké zpracování těchto částí je značně neúplné a ani osobně nemohu v této oblasti předložit komplexní, uzavřený výzkum, moje následná tvrzení mají spíše hypotetický charakter. Jedná se o takové badatelské hypotézy, které se zakládají na dílčích znalostech a v budoucnu - ve znamení Gadamerova hermeneutického kruhu ${ }^{59}$ - budou průběžně korigovány. Prozkoumání Kollárovy činnosti v oblasti církevního a veřejného života je ze všech částí dané problematiky zcela jistě časově nejnáročnější. Musí zahrnout nejen obsahový a formální rozbor existujících kázání, průzkum sítě kontaktů, založený na rozboru kompletní korespondence, ${ }^{60}$ ale i zpracování německých, slovenských a mad’arských protokolů pešt’ské evangelické církevní obce ${ }^{61}$ nemluvě o sekundárních pramenech, korespondenci, vzpomínkách současníků. ${ }^{62} \mathrm{Z}$ mé stávající pozice je dobře patrná existence silné vazby na evangelickou duchovně pastorační praxi a zasazení Kollárových kázání do racionalistické teologické tradice. ${ }^{63}$ Zcela v jejím duchu je v církevních promluvách prezentace duchovních nebo osobních prvků minimalizována a nikdy se nevyskytuje před obecným. Osobní prvek se dostává do kázání pouze tehdy, pokud je zároveň spojen se společenstvím a může sloužit jako argument pro potvrzení hlavních

59) Gadamer, Hans-Georg: Hermeneutik I. Wahrheit und Methode. Grundzüge einer Philosophischen Hermeneutik, Mohr Siebeck, Tübingen, 2010. Viz kapitola Der hermeneutische Zirkel und das Problem der Vorurteile, s. 270-281. Mad’arsky: Gadamer, Hans-Georg: Igazság és módszer (Pravda a metoda), Gondolat, Budapest 1984.

60) K metodám rozboru sítě kontaktů viz: Takács Károly (szerk.): „Kapcsolatháló elemzés; Társadalmi kapcsolathálók elemzése“. Dostupné online: http://www.tankonyvtar.hu/hu/tartalom/tamop425/0010_2A_08_Kapcsolathalo_ elemzes_szerk_Takacs_Karoly/ch04.html. Staženo 2017-01-23. 11:18.

K aplikaci této politologické metody na dobu reforem viz studie Józsefa Demmela: „Az irodalom (szociális) hálója. Közelítések Vahot Imréhez“ (/Sociální/ sít literatury. Cesty k Imre Vachotovi), Sic Itur ad Astra, 59, 2009, s. 253-268. Sítí kontaktů Kollára se v souvislosti s prenumerací jeho sbírky lidových písní zabývá: Demmel, József: „Népdalok és előfizetők. Adalékok Ján Kollár kapcsolathálójához“ (Lidové písně a předplatitelé. Poznámky ke kontaktům J. K.), ELTE BTK, Szláv és Balti Filológiai Intézet, Szlovák szak, 19. 4. 2007, s. 19, seminární práce.

61) Jedná se o materiály Evangelického zemského archivu (Evangélikus Országos Levéltár), které jsou ve značně poškozeném stavu, rovněž listy v matrikách jsou na mnoha místech poškozené, proto je nevyhnutelné jejich co nejrychlejší ošetření a popis.

62) Důležité jsou vzpomínky Kollárova spolupracovníka, pastora Józsefa Székácse. Kertész Botond (ed.): Székács József visszaemlékezései (Vzpomínky J. Sz.), Budapest, Akadémiai Kiadó 2008.

63) Hladký, Juraj - Krasnovská, Elena (eds.): Slovenská kazatel’ská tvorba 19. storočia v dejinných súvislostiach a v spoločenskom kontexte obdobia. Materiály z vedeckej konferencie (Trnava 12.-14.septembra 2005). Spolok svätého Vojtecha - Katedra slovenského jazyka a literatúry Pedagogickej fakulty Trnavskej univerzity v Trnave, Trnava 2006. 
premis. Z tohoto hlediska je např. typické kázání Truchlořeč, při pohřebu zamordovaného, ve kterém kazatel rozebírá okolnosti vraždy slovenského voraře. Nejprve popisuje výchozí tezi, podle které národnostní nenávist/nesnášenlivost škodí stavu celé společnosti a teprve potom pro objasnění této teze popisuje v poznámce pod čarou - trestný čin. ${ }^{64}$ Dostatečně silným podnětem k překročení rámce racionalistického kázání se pro Kollára stává národní apologie. Příkladem může být zejména kázání, v němž je pojednáno o slovanských dobrých vlastnostech. ${ }^{65}$ Napětí mezi vypjatě manifestovanou národní věcí a kontextem církevního společenství i veřejného života přitom můžeme vnímat jako zřetelnou paralelu dvojího estetického ukotvení Kollárových básnických děl, rozpjatých mezi klasicismem a romantismem. Evangelický církevní rámec se ukázal jako užitečný i v oblasti školní výuky v národním jazyce. Pro slovenské žáky peštské evangelické církevní obce napsal Kollár slabikáŕ ${ }^{66}$ a čítanku ${ }^{67}$, které splňují požadavky osvícenského utilitarismu, a přitom v duchu národního romantismu konvenují i stále silnějším očekáváním výuky v mateřském jazyce. Právě v Čítance je obsažen jeden $\mathrm{z}$ textů, které jsou z našeho hlediska přímo emblematické - malý katechismus národních vědomostí pro děti s názvem Kratičká známost národu slowanského. ${ }^{68}$ Můžeme shrnout, že spojení s církevně-společenským rámcem včleňuje Kollára především do osvícenské tradice, avšak psychologické rysy doprovázející tuto církevně-společenskou roli připomínají spíše sebe-stylizaci národního apoštola romantického střihu. Jenže středoevropští národní apoštolové mohou - nahlíženo optikou jiného národa - ukazovat přirozeně i negativní obraz (viz mad’arská nebo polská recepce Kollára).

K nejdůležitějším žánrům, jejichž cílem bylo racionální poznání širšího světa a šíření poznání, patřil v době osvícenství cestopis. Středoevropští představitelé tohoto žánru se vydávali především do západní Evropy, protože „své bdělé oči

64) Kollár, Ján: „Truchlořeč, při pohřebu zamordowaného“, in týž: Nedělní, svátečné i př́ležitostné Kázně a Řeči od Jana Kollára, cjrkwe ewangelické Peštansko-Budjnské sl. b. K. učené Společnosti krakowské úda, Pešt', Trattner a Karoli 1831, s. 630-635.

65) Kiss Szemán, Róbert: „Historičnost a kreace neboli Dobré wlastnosti Národu Slowanského?“, Česká literatura, 2009, 6, s. 802-816.

66) Šlabikár̆ pro Djtky, s Přjdavkem latinských, uherských a německých článků k čjtánj. Péčj a nákladem Cjrkwe ew. slowenské Pesstansko-Budjnské. K Šlabikáři tomuto přináležj: 1. Čjtanka 2. Pěknopjsebnost. Typ. Matěj Trattner z Petróze. Pesst 1826.

67) Čjtanka anebo Kniha k Čjtánj pro mládež we školách slowanských w městech a w dědinách, w Budjně w Králowské uniwersické tiskárně 1825.

68) Čjtanka anebo Kniha k Čjtánj pro mládež we školách slowanských $w$ městech a $w$ dědinách, w Budjně w Králowské uniwersické tiskárně 1825, s. 202-209. 
obraceli k Pařiži“i“69 nebo k německým osvícenským kulturním centrům. ${ }^{70}$ Tito cestopisci si kromě německých a západoevropských oblastí často volili jako cíl cesty i klasické oblasti jižní Evropy. $Z$ tohoto hlediska odpovídají Kollárovy cesty oběma tužbám: navštívil habsburskou část severní Itálie i Německo. Kromě toho, že Kollárovy cestopisy vykazují jasný záměr naplnit osvícensko-racionalistické poznávací funkce, nesou v sobě rovněž specifické romantické rysy. Jedním z nich je romantická touha (Sehnsucht) po vymanění se z macešské vlasti. Druhým charakteristickým rysem je, že i přes veškerou snahu o objektivitu při popisu cesty a př́rody se jednoznačně prosazují rysy autorského subjektu. ${ }^{71}$ Třetí charakteristika Kollárových cestopisů se váže $\mathrm{k}$ národnímu emblematismu: $\mathrm{z}$ uherské, ${ }^{72}$ italské i německé kulturní tradice autorský záměr neustále vybírá, transponuje a pořádá do samostatného systému ony prvky, které může považovat za „vlastní, tedy za domnělé slovanské kulturní dědictví na cizí půdě. Jako emblematický př́klad můžeme zmínit část benátské kapitoly o pobřeží Slovanů. ${ }^{73}$

Kollár je však přesto nejvíce romantický v oblasti vědy. Herderovsko-goethovská intence ke sběru a prezentaci slovenských lidových písní zůstala pro Kollára výzvou po celý život, ${ }^{74}$ takže po náročných přípravných pracích mohla v roce 1834 spatřit světlo světa sbírka lidových písní. ${ }^{75}$ Mad’arská historiografie z období po pozitivismu často používá pro charakteristiku romantických vědeckých teorií pojem "fantomatický“ (délibábos). Fantomatická je tedy taková jazykověda, která uvádí jazykovou příbuznost mad’arštiny se sumerštinou nebo s hebrejštinou, fantomatická je taková historická práce (např. Istvána Horvátha), která si cestu Mad’arů před jejich usazením ve střední Evropě představovala jako pout přes Itálii a etnicky je považovala za příbuzné s Etrusky nebo s Pelasgy. ${ }^{76}$ Tímto způsobem je fantomatické i Kollárovo etymologizování, následující v neposlední

69) Poslední verš z básně mad’arského osvícenského básníka Jánose Batsányiho A franciaországi változásokra (Na francouzské změny): „Vigyázó szemetek Párizsra vessétek“.

70) Faktorová, Veronika: Mezi poznáním a imaginací. Podoby obrozenského cestopisu, Praha, Nakladatelství ARSCI 2012.

71) Cestopis obsahující cestu do Horní Italie a odtud přes Tyrolsko a Baworsko, se zvláštním ohledem na slawjanské žiwly roku 1841. konanau a sepsanau od Jana Kollára S Wyobrazeními a Př́lohami též i se Slowníkem slawjanských umělcůw wšech kmenůw od neystaršich časůw k nynějšímu wěku, s krátkým žiwotopisem a udáním znamenitějších, zwláště národních, wýtworůw, Pešt', Trattner Károlyiho 1843. Popis Zalaváru na s. 10-14.

72) Týž tamtéž: etymologie jména Veszprém, s. 4.

73) Týž tamtéž: Díl II. Část I. Benátky, s. 76-152.

74) Ján Kollár - Pavel Jozef Šafárik: Piesne svetské ludu slovenského v Uhorsku. Diel prvý a druhý, Tatran, Bratislava 1988.

75) Národnié Zpiewanky čili Pjsně swětské Slowáků w Uhrách gak pospolitého lidu tak i wyššjch stawů, sebrané od mnohých, w pořádek uwedené, wyswětlenjmi opatřené a wydané od Jana Kollára. Djl perwý. Wydánj hogné rozmnožené i perwé dwa tištěné swazečky w sobě obsahugjcj. W Budjně w Král. universické tiskárně. 1834.

76) Szilágyi, János György: Pelasg ősök nyomában (Po stopách Pelasgů jako předků), Atlantisz Könyvkiadó -Szépművészeti Múzeum, Budapest 2010. 
řadě právě příklad Istvána Horvátha. ${ }^{77} \mathrm{~V}$ případě Kollárovy posmrtně vydané Staroitalie Slavjanské převážil definitivně národní romantický imaginarismus nad osvícenským racionalismem. ${ }^{78}$ Není úchvatnějšího prožitku, než jaký nám poskytuje právě toto dílo, kde se svévolně vedle sebe řadí do tabulek uspořádané italské a slovanské místní názvy, až člověk získá podezření, že se jedná o horečnaté představy nějakého pomatence. Jsme zde svědky vytvoření ojedinělého a ve své svévolnosti nahodilého vědeckého mytologického systému, který s výjimkou autora nikdo neocenil a nepochopil. Tím se Kollár, v zoufalé snaze zapustit slovanskou kulturu do půdy starověké Itálie, jako vědec definitivně zabořil do močálu fantomatické vědeckosti - o tomto díle a o této skutečnosti rozpačitě mlčeli jak jeho současníci, tak i recepce.

$\mathrm{V}$ posledních pěti letech autorova života byla pro tuto definitivní romantickou vědeckost příznačná i protikladně, konzervativně zaměřená aktivita ve veřejném životě. Kollárovo odmítnutí nového slovenského literárního jazyka ve 40. letech se z politického a osobního zájmu jevilo jako odůvodněné. Znamenalo logickou obranu československé jazykové a kulturní jednoty, a kromě toho vycházelo z osobních obav, že se jeho tvorba dostane mimo nový slovenský kulturní kánon. Kollár se mohl právem domnívat, že nový slovenský kulturní korpus bude po vyloučení českého jazyka ještě chudší a že Slovákům hrozí nejen marginalizace, ale i pro středoevropský romantismus tak příznačný děsivý přízrak národní smrti. Aby tomuto zabránil, zorganizoval sběr a shromáždění materiálu a jeho publikování ve sbírce Hlasowé... ${ }^{79}$, jejíž vážená autorská garda nenechává v této otázce nikoho na pochybách, na čí straně stojí.

Politické a společenské otřesy mad’arské revoluce a osvobozeneckého boje 1848/49 (detronizace Habsburků, ozbrojená povstání uherských národností atd.) svým způsobem $\mathrm{v}$ Kollárových očích potvrzovaly škodlivost politického radikalizmu a neudržitelnost s ním spojeného romantického národotvorného procesu. V rámci porevoluční obnovy si Habsburkové s dobrým citem vybrali

77) Kiss Szemán, Róbert: „Dejinnost’ a kreácia - paralely v historickej tvorbe a svetonázore Jána Kollára a Istvána Horváta“, in Kákošová, Zuzana - Vojtech, Milo: Slovenská literatúra 18. a 19. storočia. História, teória, interpretácia, Bratislava, Univerzita Komenského v Bratislave, Filozofická fakulta 2007, s. 96-117.

78) Staroitalia slavjanská aneb objevy a důkazy živlů slavských v zeměpisu, v dějinách a v bájeslovi, zvláště v řeči a v literatuře nejdávnějších vlaských a sousedních kmenů, z kterých zřejmo, že mezi prvotními osadníky a obyvateli této krajiny i Slavjané nad jiné četnější byli. Sepsal Jan Kollár, doktor filosofie, professor slav. starovědy na Cís. král. universitě vídenské, rytír̆ Řádu Františka Josefa, čestný úd společnosti Českého Museum, úd Společnosti náukv Praze a v Krakově, čestný úd Společnosti pro dějiny a starožitnosti jihoslavjanské v Záhřebě, Srbské slovesnosti v Bělehradě, Společnosti pro dějiny a starožitnosti pomořanské ve Štětíně, Společnosti pro dějiny a starožitnosti ruské v Moskvě a Společnosti prátel dějin i starožitnosti v Odese. Ve Vídni. V Císařské královské dvorské a státní tiskárně. 1853.

79) „Hlasowé o potřebě jednoty spisowného jazyka pro Čechy, Morawany a Slowáky“, Spisů musejních číslo XXII. W Praze, w kommissí u Kronbergra i Řiwnáče, 1846. 
osobnosti, které jako odměnu za jejich loajalitu pustili blíž k moci. Kollár dostal od dvora jednak možnost vytvořit v horních Uhrách slovanský školní systém ${ }^{80}$, jednak univerzitní katedru, která znamenala vrchol jeho kariéry ve veřejném životě. Vojtěch Jirát zavádí pojem „empírový klasicismus“, který nevztahuje pouze na Kollára, ale na celou slovenskou básnickou generaci uherského původu, a který je výstižný, proto, že vyjadřuje jak onen druh uherské klasické a klasicistní tradice, o níž byla řeč v druhé části, tak ukazuje i na loajální vztah $\mathrm{k}$ vládnoucí moci, který $\mathrm{v}$ případě Kollára překročil obvyklou míru. ${ }^{81} \mathrm{Když} \mathrm{se}$ Kollár rozhodl, že opustí Pešt a přestěhuje se do Vídně, mohl si právem myslet, že jako uherský Slovan vyšel vítězně z boje s mad’arským nacionalismem, že v zájmu obrany českého jazyka zabránil šíření nové literární slovenštiny, že svým odporem proti demokratickému radikalismu a přitakáním osvícenskému absolutismu získal - díky přízni panovníka - i svoji životní odměnu.

V rámci shrnutí můžeme ke stávající recepci Kollárovy osobnosti a díla dodat, že obojí výrazně začlenilo do uherské latinské tvorby a do klasicismu, přičemž tato tendence není překážkou $\mathrm{k}$ tomu, aby se v dílech zachycujících jednotlivé autorovy role plně neprojevovaly i romantické rysy. Kollárovu tvorbu je tedy možné umístit na takové ose tradice, kde stř́davě osciluje mezi klasicismem konce 18. století a romantikou poloviny 19. století. Podrobnější analýza a systematičtější popis je na tomto poli ovšem ještě záležitostí budoucnosti.

\section{Prameny}

BOILEAU, Despreaux

1832 Uměnj básnjřské, které we francouzském gazyku Boileau Despreaux we čtyřech zpěwjch složil, w českoslowenský pak gazyk přeložil Bohuslaw Tablic (Budín: Král. universická tiskárna)

GERBÓCOVÁ, Jarmila

1991 Ján Kollár v literatúre od roku 1952. Bibliografia (Bratislava: Ústav slovenskej literatúry, strojopis)

80) Karásek, Josef (ed.): „Johann Kollár: Gedanken und Plan zu einer zeitgemäszen Reorganisirung der Schulen und des gesammten Volkserziehungswesens in der österreichischen Monarchie besonders in der Slowakei“, in Kollárova Dobrozdání a Nástin životopisný z roku 1849. Vydal a úvodem opatřil D. Josef Karásek. Sbírka pramenův ku poznání literárního života v Čechách, na Moravě a v Slezsku. Skupina druhá. Korespondence a cizojazyčné prameny. Číslo 7. V Praze. Nákladem České akademie císaře Františka Josefa por vědy, slovesnost a umění. 1903.

81) Jirát aplikuje tento pojem na napoleonskou generaci celého slovenského osvícenství: „Generace empírových klasicistů, narozených mezi 1793-1798, odlišuje se od preromantiků spíš místně než věkem. Nejvýraznější z nich přicházejí ze Slovenska, tak Kollár, Šafařík, Palacký, Hollý (který však píše slovensky)“- Jirát, Vojtěch: „Lyrika českého obrození", in Jirát, Vojtěch: Portréty a studie. Odeon, Praha, 1978, s. 24-32. 
KARÁSEK, Josef (ed.)

Sbírka pramenův ku poznání literárního života v Čechách, na Moravě a v Slezsku. Skupina druhá. Korespondence a cizojazyčné prameny. Čislo 7 (Praha: Česká akademie císaře Františka Josefa pro vědy, slovesnost a umění)

\section{KERTÉSZ Botond (ed.)}

2008 Székács József visszaemlékezései (Budapest: Akadémiai Kiadó)

KOLLÁR, Jan

1843 Cestopis obsahujicí cestu do Horní Italie a odtud přes Tyrolsko a Baworsko, se zvláštním ohledem na slawjanské žiwly roku 1841. konanau a sepsanau od Jana Kollára. S Wyobrazeními a Přilohami též i se Slowníkem slawjanských umělcůw wšech kmenůw od neystarších časůw k nynějšimu wěku, s krátkým žiwotopisem a udáním znamenitějščch, zwláště národních, wýtworůw (Pešt: Trattner Károlyi)

1825 Čjtanka anebo Kniha k Čjtánj pro mládež we školách slowanských w městech a w dèdinách (Budín: Králowská uniwersická tiskárna)

1903 „Gedanken und Plan zu einer zeitgemäszen Reorganisirung der Schulen und des gesammten Volkserziehungswesens in der österreichischen Monarchie besonders in der Slowakei“, in Kollárova Dobrozdáni a Nástin životopisný z roku 1849. Sbírka pramenưv ku poznání literárního života v Čechách, na Moravě a v Slezsku. Skupina druhá. Korespondence a cizojazyčné prameny, číslo 7 (Praha: Česká akademie císaře Františka Josefa pro vědy, slovesnost a umění), s. 1-45

1846 „Hlasowé o potřebě jednoty spisowného jazyka pro Čechy, Morawany a Slowáky“, Spisů musejních číslo XXII (Praha: Kronbergr i Řiwnáč)

1834 Národnié Zpiewanky čili Pjsně swětské Slowáků w Uhrách gak pospolitého lidu tak i wyššjch stawů, sebrané od mnohých, w pořádek uwedené, wyswětlenjmi opatřené a wydané od Jana Kollára. Djl perwý. Wydánj hogné rozmnožené i perwé dwa tištěné swazečky w sobě obsahugjcj (Budín: Král. Universická tiskárna)

1831 Nedělní, svátečné i př́ležitostné Kázně a Řeči od Jana Kollára, cjrkwe ewangelické Peštansko-Budjnské sl. b. K. učené Společnosti krakowské úda (Pešt: Trattner a Karoli)

1863 „Paměti z mladších let života“, in Spisy Jana Kollára. Díl čturtý. Cestopis druhý a Paměti z mladších let života Jana Kollára sepsány od něho samého (Praha: I. L. Kober), s. 108-111

1853 Staroitalia slavjanská aneb objevy a důkazy živlů slavských v zeměpisu, v dějinách a v bájeslovi, zvláště v řeči a v literatuře nejdávnějšich vlaských a sousedních kmenů (Vídeň: Císařská královská dvorská a státní tiskárna) 1826 Šlabikár̆ pro Djtky, s Přjdavkem latinských, uherských a německých článkủ k čjtánj. Péčj a nákladem Cjrkwe ew. slowenské Pesstansko-Budjnské (Pesst: Matěj Trattner z Petróze)

1853 Staroitalia slavjanská aneb objevy a důkazy živlů slavských v zeměpisu, v dějinách a v bájeslovi, zvláště v řeči a v literatuře nejdávnějšich vlaských a sousedních kmenů, z kterých zřejmo, že mezi prvotními osadníky a obyvateli této krajiny i Slavjané nad jiné četnější byli. Sepsal Jan Kollár, doktor filosofie, professor slav. starovědy na Cís. král. universitě vídenské, rytír Řádu Františka Josefa, čestný úd společnosti Českého Museum, úd Společnosti náuk v Praze a v Krakově, čestný úd Společnosti pro dějiny a starožitnosti jihoslavjanské v Záhřebě, Srbské slovesnosti $v$ Bělehradě, Společnosti pro dějiny a starožitnosti pomořanské ve Štětíně, Společnosti pro dějiny a starožitnosti ruské v Moskvě a Společnosti prátel dějin i starožitnosti v Odese (Vídeň: Císařská královská dvorská a státní tiskárna)

1831 „Truchlořeč, při pohřebu zamordowaného“, in týž Nedělní, svátečné i př́ležitostné Kázně a Řeči od Jana Kollára, cjrkwe ewangelické Peštansko-Budjnské sl. b. K. učené Společnosti krakowské úda (Pešt: Trattner a Karoli), s. $630-635$ 
KOLLÁR, Jan - ŠAFÁRIK, Pavel Jozef

1988 Piesne svetské ludu slovenského v Uhorsku. Diel prvýa druhý (Bratislava: Tatran)

KOLLÁR, Jan - PUTNA, Martin C.

2014 Slávy dcera. Báseň lyricko-epická v pěti zpěvich. Překlad a výklad Slávy dcery z panslavistického mýtu do kulturní historie (Praha: Academia)

ORMIS, Jan V.

1954 Bibliografia Jána Kollára (Bratislava: Vydavatelstvo Slovenskej akadémie vied)

SZÉKÁCS József

2008 Visszaemlékezések (Budapest: Akadémiai Kiadó)

SZINNYEI József:

2017 „Magyar írók élete és munkái“, http://mek.oszk.hu/03600/03630/html/h/h07681.htm. Staženo 4. 7. 2017. $12: 08$

\section{LITERATURA}

\section{BÁNKI György}

2016 A legnagyszerübb könyv a nárcizmusról (Místo vydání neuvedeno: Ab Ovo Kiadó)

CURTIUS, Ernst Robert

MCMXLVIII [1948] Europäische Literatur und lateinisches Mittelalter (Bern: A. Francke AG-Verlag)

EVEN-ZOHAR, Itamar

1990 „Polysystem Theory“, Poetics Today, č. 1, s. 9-26 http://www.tau.ac.il/ itamarez/works/books/ezpss1990.pdf

DEMMEL József 2007 Népdalok és előfizetők. Adalékok Ján Kollár kapcsolathálójához (Budapest: ELTE BTK, Szláv és Balti Filológiai Intézet, Szlovák szak, 19. 4. 2007, seminární práce)

FAKTOROVÁ, Veronika

2012 Medzi poznáním a imaginací. Podoby obrozenského cestopisu (Praha: Nakladatelství ARSCI)

FRIED István

1986 „Verspätung, Neuerung, Periodisierung in der ostmitteleuropäischen Romantik“, Studia Slavica, 32, č. 1-4, s. 3-30

GADAMER, Hans-Georg 2010 Hermeneutik I. Wahrheit und Methode. Grundzüge einer philosophischen Hermeneutik (Tübingen: Mohr Siebeck) 
HLADKÝ, Juraj - KRASNOVSKÁ, Elena (eds.)

2006 Slovenská kazatel'ská tvorba 19. storočia v dejinných súvislostiach a v spoločenskom kontexte obdobia. Materiály z vedeckej konferencie (Trnava: Spolok svätého Vojtecha - Katedra slovenského jazyka a literatúry Pedagogickej fakulty Trnavskej univerzity v Trnave)

\section{GROSFOGUEL, Ramón}

2011 „A politikai gazdaságtan és a posztkoloniális tanulmányok gyarmatmentesítése. Transzmodernitás, határgondolkodás és globális gyarmatiság“, Eszmélet 23, č. 92, s. 39-70

HEIDEGGER, Martin

1989 Lét és idő (Budapest: Gondolat)

HORVÁTH János

2005 „A magyar irodalom fejlődéstörténete“, in KOROMPAY H. János - KOROMPAY Klára (eds.): Horváth János irodalomtörténeti munkái I. (Budapest: Osiris Kiadó), s. 57-452

\section{IMRE Mihály}

1995 „Magyarország panasza“. A Querela Hungariae toposz a XVI-XVII. század irodalmában (Debrecen: Kossuth Egyetemi Kiadó)

JAUSS, Hans Robert

1977 Alterität und Modernität der mittelalterlichen Literatur (München: Fink)

JIRÁT Vojtěch

1978 „Lyrika českého obrození“, in týž: Portréty a studie (Praha: Odeon), s. 24-32

KÁKOŠOVÁ, Zuzana - VOJTECH, Milo (eds.)

2007 Slovenská literatúra 18. a 19. storočia. História, teória, interpretácia (Bratislava: Univerzita Komenského v Bratislave, Filozofická fakulta)

KERMODE, Frank

1979 „Institutional Control of Interpretation“, Salmagundi 43, Winter, s. 72-86

\section{KISS SZEMÁN Róbert}

2007 „Dejinnost a kreácia - paralely v historickej tvorbe a svetonázore Jána Kollára a Istvána Horváta“, in KÁKOŠOVÁ, Zuzana - VOJTECH, Milo (eds.): Slovenská literatúra 18. a 19. storočia. História, teória, interpretácia (Bratislava: Univerzita Komenského v Bratislave, Filozofická fakulta), s. 96-117

2009 „Historičnost a kreace neboli Dobré wlastnosti Národu Slowanského?“, Česká literatura, 57, č. 6, s. 802-816

2005 „Jan Kollár, velký kreátor. Grundlage II. Emblematický národopis: zeměpis, národopis, přírodopis a zoologie“, Slovanský přehled, 91, s. 557-563

2007 „Od nářku Uher k nářku Slavie v díle Jana Kollára“, in VYČICHLO, Jaroslav - VIKTORA, Viktor (eds.): Jeden jazyk naše heslo bud' IV. Český romantismus - jiskření a záblesky (Plzeň: Spolek divadelních ochotníků v Radnicích - Studijní a vědecká knihovna Plzeňského kraje), s. 157-170

2012 „Slávy dcera“, Slovenská literatúra LIX, č. 2, s. 89-111 
2014 Slovanský Goethe v Pešti. Ján Kollár a národní emblematizmus středoevropských Slovanů (Praha: Akropolis)

KOROMPAY H. János - KOROMPAY Klára (eds.):

Horváth János irodalomtörténeti munkái I. (Budapest: Osiris Kiadó)

KUHN, Thomas S.

1996 The Structure of Scientific Revolutions. Third Edition (Chicago: The University of Chicago Press)

MACURA, Vladimír

1995 Znamení zrodu. České národní obrození jako kulturní typ (Praha: H \& H)

MAN, Paul de

1997 „Az önéletrajz mint arcrongálás“, Pompeji, č. 2-3, s. 93-107. V elektronické podobě: http://www. irodalomelmelet.atw.hu/deman.pdf 2016. 4. 20. 16:33.

1979 „Autobiography as De-facement“, Comparative Literature, MLN 94, 5 (Dec.), s. 919-930

\section{MATUS László}

2000 A Pesti Szlovák Evangélikus Gyülekezet (Piliscsaba: Pázmány Péter Katolikus Egyetem Bölcsészettudományi Kar, diplomová práce, obor historie)

2000 „Ján Kollár és a pesti szlovák evangélikusok asszimilációjának problémája a 19. század húszas éveiben“, Világtörténet, č. 2, s. 61-73

RICOEUR Paul

1970 Freud und Philosophy. An Essay on Interpretation (New Haven: Yale University Press)

SCHWARTNER, Martin von

1798 Statistik des Königreichs Ungern. Ein Versuch (Pest: M. Trattner)

1809 Statistik des Königreichs Ungern, 2. vydání (Ofen: Gedruckt mit Königl. Univerisitäts-Schriften)

SHEARMAN, John

1963 „Maniera as an Aesthetic Ideal“, in The Renaissance and Manierism. Studies in Western Art (Princeton: Princeton University Press), sv. II, s. 202-208

SZARKA László (ed.)

2011 A modern szlovák nacionalizmus évszázada 1780-1918 - Párhuzamos nemzetépités a multietnikus Magyar Királyságban (Století moderního slovenského nacionalismu, 1780-1918 (Budapest: Akadémiai Kiadó)

\section{SZAUDER József}

1980 Az éj és a csillagok. Tanulmányok Csokonairól (Budapest: Akadémiai Kiadó)

1980 „Az iskolás klasszicizmus“, in týž Az éj és a csillagok. Tanulmányok Csokonairól (Budapest: Akadémiai Kiadó), s. 36-56

\section{SZIKLAY László}

1963 „Einige methodologische Fragen der vergleichenden Literaturgeschichte“ (Die ungarisch-slavischen literarischen Beziehungen), Studia Slavica, 9, s. 331-335 
Róbert Kiss Szemán

Dílo Jana Kollára ve světle klasicistních a romantických tendencí uherských literatur

SZILÁGYI János György

2010 Pelasg ősök nyomában (Budapest: Atlantisz Könyvkiadó - Szépművészeti Múzeum)

SZÖRÉNYI László

1999 Studia Hungarolatina. Tanulmányok a régi magyar és neolatin irodalomról (Budapest: Kortárs Kiadó)

TAKÁCS, Károly (szerk.)

2011 Kapcsolatháló elemzés. Társadalmi kapcsolathálók elemzése (Budapest: Corvinus Egyetem) http://www. tankonyvtar.hu/hu/tartalom/tamop425/0010_2A_08_Kapcsolathalo_elemzes_szerk_Takacs_Karoly/index.html. 18. 9. 2011

TARANENKOVÁ, Ivana (ed.)

2013 Možnosti autobiografickosti (Bratislava: Ústav slovenskej literatúry SAV - Pedagogická fakulta Trnavskej univerzity)

TARNAI Andor

1975 „A toposzkutatás története“, Literatura, 2, č. 1, s. 66-73

TARNAI Andor

1969 „Extra Hungariam non est vita... (Egy szállóige történetéhez)“, Modern Filológiai Füzetek 6 (Budapest: Akadémiai Kiadó)

TUREČEK, Dalibor a kol (eds.)

2012 České literární romantično. Synopticko-pulzační model kulturního jevu (Brno: Host)

TUREČEK, Dalibor - FAKTOROVÁ, Veronika

2010 KHM 1810-2010: Dvě století české kultury s Máchou. Katalog k výstavě v Letohrádku Hvězda 29. června - 31. ř́jna 2010 (Praha: Památník národního písmenictví)

TUREČEK, Dalibor - URVÁLKOVÁ, Zuzana (eds.)

2006 Mezi texty a metodami (Olomouc: Periplum)

VOJTECH, Miloslav

2004 Literatúra, literárna história a medziliterárnost' (Bratislava: Filozofická fakulta Univerzity Komenského)

VYČICHLO, Jaroslav - VIKTORA, Viktor (eds.)

2007 Jeden jazyk naše heslo bud' IV. Český romantismus - jiskření a záblesky (Plzeň: Spolek divadelních ochotníků v Radnicích - Studijní a vědecká knihovna Plzeňského kraje)

\section{WÉBER Antal}

1974 Irodalmi irányok, távlatból. Fejezetek a felvilágosodás és a reformkor irodalmának történetéböl (Budapest: Szépirodalmi Könyvkiadó) 


\section{ZAJAC, Peter}

2006 „Literárne dejepisectvo ako synoptická mapa“, in TUREČEK, Dalibor - URVÁLKOVÁ, Zuzana (eds.): Mezi texty a metodami (Olomouc: Periplum), s. 13-22

Róbert Kiss Szemán, kiss.szeman.robert@gmail.com, Univerzita Eötvöse Loránda $v$ Budapešti, Mad’arsko/University of Eötvös Loránd in Budapest, Hungary 